УДК 347.962+347.97/.99

\author{
I. С. Лісна \\ кандидат юридичних наук, доцент, \\ завідувач кафедри історії та теорї держави і права \\ Чорноморського національного університету ілені Петра Могили \\ T.E. Михайлів \\ аспірант кафедри історії та теорії держави і права \\ Чорноморського національного університету імені Петра Могили
}

\title{
ВИКОРИСТАННЯ ЗАРУБІЖНОГО ДОСВІДУ ФУНКЦІОНУВАННЯ СУДОВИХ СИСТЕМ ПІД ЧАС ПРОВЕДЕННЯ СУДОВОЇ РЕФОРМИ В УКРАЇНІ
}

Світовим надбанням можна вважати низку міжнародних нормативно-правових актів, які визначають засади, тобто принципи, на яких має грунтуватися та функціонувати судова влада демократичної правової держави. Це принципи як власне судової діяльності, так і побудови судоустрою.

Попри всю важливість питання міжнародних стандартів, їх додержання і застосування у національному законодавстві, необхідно зазначити, що серед науковців немає єдиної думки щодо визначення поняття «міжнародні стандарти». Такого визначення не містить і жодний офіційний міжнародно-правовий документ, яким закріплено такі стандарти.

Так, термін «міжнародно-правові стандарти» вважається найбільш прийнятним позначенням для комплексу закріплених у різноманітних міжнародних документах норм, що відображають певні уніфіковані (стандартизовані) правила поведінки суб'єктів міжнародного права у тих чи інших сферах міждержавного співробітництва. На думку фахівців, їх значення для національного законодавства України полягає в тому, що вони слугують своєрідним орієнтиром, а також становлять відносно автономну щодо нього систему. Водночас такі норми потребують конкретизації і доповнення з боку норм внутрішньодержавного права, оскільки містять найбільш загальні положення, які в кожній окремій державі мають свою специфіку [1].

На думку В. Баймуратова, підписання двома i більше державами міжнародних угод із переважного кола питань міжнародних відносин, їх легалізація та реалізація - це процес розробки, визнання, прийняття на себе зобов'язань із виконання і реалізації міжнародних правил поведінки, що мають нормативний, типологічний, стереотипний характер, і внаслідок своєї обов'язковості, повторюваності та передбачуваності стають міждержавними, а в широкому розумінні - міжнародними стандартами [2]. Однак повністю погодитися з думкою автора не можна, оскільки не всі міжнародні акти укладені або прийняті на міжнародній арені стають міжнародними стандартами.
Л. Луць під час дослідження європейських міждержавних правових систем визначив загальновизнані європейські правові стандарти як єдині, типові принципи й норми, які зафіксовані в основних джерелах права регіональних міждержавно-правових систем та є мінімальними правовими вимогами щодо правових систем держав-учасниць [3, с. 96$]$.

В. Бринцев зауважує, що під стандартами (у контексті права) розуміють установлені міжнародно-правовими актами певні мінімальні вимоги, дотримуватися яких зобов'язані всі держави у процесі національної законотворчості [4, с. 31]. Однак кожен міжнародно-правовий акт може носити як обов'язковий, так i необов'язковий характер. А роль цих «необов'язкових» актів і директив надзвичайно важлива, оскільки саме вони тлумачать та роз'яснюють стандарти, закріплені в обов'язкових міжнародних документах, що приймаються за результатами збору інформації та вивчення конкретних питань у правових системах різних країн, акумулюють їх досвід у тих чи інших сферах, а також містять висновки, аналіз оцінюваних процесів і практичні рекомендації до впровадження тих чи інших принципів

Наприклад, Міжнародний пакт про громадянські і політичні права та Конвенція про захист прав людини і основоположних свобод є частиною національного українського законодавства згідно зі ст. 9 Конституції України та підлягають обов'язковому застосуванню [5]. При цьому не є частиною нашого законодавства, для прикладу, Основні принципи незалежності судових органів, схвалені резолюціями Генеральної Асамблеї ООН №№ 40/32, 40/146 від 29 листопада та 13 грудня 1985 року, Бангалорські принципи поведінки суддів від 19 травня 2006 року, схвалені Резолюцією Економічної та Соціальної Ради ООН № 2006/23 від 27 липня 2006 року, рекомендації Комітету Міністрів Ради Європи державам-членам, висновки Консультативної ради європейських суддів до уваги Комітету Міністрів Ради Свропи. Такі документи в преамбулах, як правило, містять вказівку про те, що вони рекомендуються до виконання 
і вжиття заходів на національному рівні з урахуванням умов та традицій кожної країни.

Визнані прогресивною міжнародною спільнотою стандарти в сфері судочинства містяться в різноманітних за своєю правовою природою документах і мають різний рівень - загальносвітовий чи європейський. 3 огляду на це міжнародні стандарти у сфері судочинства можна поділити на дві групи: 1) міжнародні стандарти, які містяться у загальносвітових документах; 2) загальновизнані європейські стандарти, які закріплені в європейських міжнародних правових актах.

До першої групи загальносвітових документів, у яких містяться міжнародні стандарти у сфері судочинства, належать такі документи:

- правові акти, розроблені ООН;

- документи Юридичної асоціації країн азійського та тихоокеанського регіону (LAWASIA);

- акти Першої світової конференції з незалежності правосуддя;

- акти Міжнародної асоціації суддів.

До другої групи європейського рівня міжнародних стандартів у сфері судочинства належать такі документи:

- принципи та норми, закріплені в міжнародних документах, ухвалених під егідою Ради Європи;

- загальновизнані міжнародні стандарти Європейського Союзу.

Враховуючи розгалуженість системи міжнародних правових актів, зокрема у сфері судочинства, яка зумовлена складною внутрішньою побудовою міждержавних організації, - ООН, Ради Європи та Європейського Союзу, О. Саленко пропонує структурувати загальновизнані міжнародні стандарти у сфері судоустрою і статусу суддів за критерієм ïx iєрархії на такі види:

1) базові універсальні міжнародні стандарти, закріплені в основоположних документах, що визначають стандарти правової держави, в тому числі щодо функціонування, ролі і статусу судової влади, а також гарантій незалежності суддів. Такими документами на міжнародному рівні є Загальна декларація прав людини від 10 грудня 1948 року, Міжнародний пакт про громадянські і політичні права від 16 грудня 1966 року, а на європейському - Конвенція про захист прав людини і основоположних свобод від 4 листопада 1950 року (Рада Європи), Хартія основних прав Європейського суду від 7 грудня 2000 року (Свропейський Союз);

2) галузеві міжнародні стандарти у сфері судочинства. На міжнародному рівні це Основні принципи незалежності судових органів, схвалені резолюціями № 40/32 та № 40/146 Генеральної Асамблеї ООН від 29 листопада та від 13 грудня 1985 року, Монреальська універсальна декларація про незалежність правосуддя 1983 року, Бангалорські принципи поведінки суддів, схвалені Резолюцією № 2006/23 Економічної та Соціальної
Ради ООН від 27 липня 2006 року, Універсальна хартія судді, схвалена Міжнародною Асоціацією суддів 1 листопада 1999 року, Пекінські тези щодо принципів незалежності суддів Юридичної асоціації країн азійського та тихоокеанського регіону (LAWASIA), прийняті відповідними діячами в галузі правосуддя в LAWASIA, а також суддями з Азії та тихоокеанського регіону в Пекіні в 1995 році та схвалені на засіданні ради LAWASIA в 2001 році, висновки, прийняті Першою експертною комісією Міжнародної асоціації суддів тощо.

На європейському рівні до таких документів належать Рекомендація № R (94) 12 Комітету міністрів Ради Європи щодо незалежності, ефективності та ролі суддів від 13 жовтня 1994 року, Висновок № 1 (2001) Консультативної ради європейських суддів до уваги Комітету міністрів Ради Свропи щодо стандартів незалежності судової влади та незмінюваності суддів від 23 листопада 2001 року тощо.

3) міжнародні стандарти, втілені у практиці міжнародних юрисдикційних органів. Ця система утворена практикою Європейського суду з прав людини та прецедентами Суду Європейського Союзу [6, с. 266-267].

Отже, міжнародні стандарти у сфері судоустрою закріплені у різних нормативно-правових актах світового та європейського значення і носять обов'язковий або рекомендаційний характер. Але, оскільки вони мають важливе значення, то мають втілюватися на національному рівні незалежно від їх характеру. Натомість національний законодавець мусить створювати відповідні передумови для їх втілення шляхом передбачення у судовому законодавстві посилання на міжнародно-правові норми, які закріплюють стандарти у сфері судочинства. Так, держави-члени Ради Європи вважають за необхідне враховувати їх положення в національних законодавствах та у практиці організації й забезпечення діяльності судової влади. Крім того, ст. 15 Статуту Ради Європи надає Комітету міністрів Ради Європи право звернутися до урядів держав-членів із запитами про вжиття заходів на виконання ухвалених ними рекомендацій [7].

3 огляду на те, що міжнародно-правових актів, які закріплюють стандарти у сфері судочинства, велике різноманіття, ми проаналізуємо найважливіші.

Монреальська універсальна декларація про незалежність правосуддя 1983 року, зокрема, визначає рекомендації щодо формування суддівського корпусу, наприклад, кваліфікації, обрання та професійної підготовки суддів, суддівський імунітет та привілеї, критерії неспроможності, адміністративні питання роботи суддів. Декларація зазначає, що призначення тимчасових суддів і призначення суддів на випробувальний термін не відповідає принципу незалежності суддів. Тому подібні форми призначення мають бути поступово 
усунені, якщо вони далі існують. Виняток становить випробувальний термін, який може бути встановлений для суддів, що призначаються на посаду вперше, але під час цього терміну та під час призначення на постійну посаду вони мають перебувати під наглядом інших суддів чи вищої ради суддів. Також передбачено повну відповідальність суддів або певного органу, більшість в якому становлять судді, за адміністративну діяльність судів, включаючи нагляд та контроль за персоналом. Разом із тим визначено найвищий пріоритет держави у сфері судоустрою, а саме забезпечення судів адекватними засобами для належного відправлення правосуддя, включаючи матеріальні засоби та приміщення, які створювали б відповідні умови для незалежної, гідної та ефективної роботи суддів, належний судовий та адміністративний персонал і достатній поточний бюджет. Термін перебування суддів на посаді, їхня незалежність, соціальні гарантії, адекватна оплата й умови праці мають гарантуватися законом і не можуть змінюватися в бік зменшення [8, с. 107].

Одним з головних підсумків сьомого Конгресу ООН з профілактики злочинності і поводження 3 правопорушниками, що проходив у Мілані (Італія) з 26 серпня по 6 вересня 1985 року, є прийняття Основних принципів незалежності судових органів. У вказаних принципах особлива увага приділена питанням забезпечення незалежності судів від інших органів державної влади та посадовців, виключної компетенції органів судової влади у питаннях правосуддя, неправомірності втручання інших органів державної влади у судову діяльність, дотримання неупередженості у вирішенні справи, а також зобов'язання державних органів забезпечувати ефективне виконання судовими органами покладених на них функцій та повноважень. У відповідності до резолюції Економічної та соціальної Ради ООН 1989/60, частина V країни-члени мають кожні п'ять років починаючи з 1988 повідомляти Генеральний Секретаріат про успіхи в імплементації Основних принципів, враховуючи рівень їх розповсюдженості, впровадження в національне законодавство, проблеми, труднощі та перепони на шляху до їх впровадження та про можливу необхідність допомоги міжнародної спільноти. Цей міжнародно-правовий акт покликаний забезпечити право кожного на справедливий і публічний розгляд у компетентному, незалежному та об’єктивному суді відповідно до принципів, проголошених в Загальній декларації прав людини (ст. 10), Міжнародному пакті про громадянські й політичні права (ст. 14) та інших документах $\mathrm{OOH}$ [9].

Оскільки Основні принципи незалежності судових органів є базовими засадами регулювання питання незалежності судових органів, а також у зв'язку з експансією виконавчої і законодавчої влад на національному і міжнародному рівнях і виникнення нових груп тиску у процесі європейської інтеграції Європейська асоціація суддів у 1993 році прийняла Європейський статут судді. Принципи, закріплені у Статуті, спрямовані на підтримання незалежності суддів для забезпечення захисту прав особи від нападів з боку держави та інших груп тиску [8, с. 51].

Загальна (Універсальна) хартія судді, ухвалена 17 листопада 1999 р. Центральною Радою Міжнародної Асоціації Суддів в Тайпеї (Тайвань), продекларувала принципи незалежного і безстороннього правосуддя. Так, під час здійснення своїх повноважень судді мусять підпорядковуватися лише закону, бути неупередженими та стриманими, мусять мати особисту незалежність та не займатися діяльністю, яка $є$ несумісною зі статусом судді. Окрім цього, Хартія містить норми щодо безпеки офісу, забезпечення необхідними умовами для суддівської діяльності, посади судді, дисциплінарної, цивільної та кримінальної відповідальності, членства у професійних асоціаціях, винагороди та підтримки. Ці норми є мінімальними загальними нормами [10].

Учасники багатосторонньої наради з приводу законів про статус суддів в Свропі, що була організована Радою Свропи 8-10 липня 1998 року, прийняли Європейську хартію про статус суддів. Мета Хартії полягає у визначенні змісту будь-якого закону про статус суддів, грунтуючись на завданнях, що мають бути досягнуті: забезпечити компетентність, незалежність та неупередженість, яких громадськість має право очікувати від судів та суддів, яким довірено захист їхніх прав. Таким чином, цей Закон не є самоціллю, а скоріше засобом досягнення того, щоб особи, чиї права мають захищатися судами і суддями, мали необхідні гарантії ефективності такого захисту. Увага також приділяється органу, незалежному від виконавчої та законодавчої влади, у складі якого щонайменше половина членів - судді, обрані їхніми колегами, і в якому було б гарантовано якнайширше представництво суддівського корпусу. Законом має бути передбачено втручання такого органу під час прийняття рішення стосовно відбору та призначення на посаду судді, підвищення по службі або припинення його повноважень [8, с. 27].

Питання незалежності суддів було розглянуто провідними діячами в галузі правосуддя в LAWASIA, а також суддями з Азії та тихоокеанського регіону, внаслідок чого у 1995 р. у Пекіні були прийняті Пекінські тези щодо принципів незалежності суддів юридичної асоціації країн азійського та тихоокеанського регіону (LAWASIA). Наголошуючи на цінності судової системи у суспільстві та задля забезпечення права кожної особи на розгляд ї̈ справи компетентним та неупередженим судом, яке проголошене у ст. 10 Загальної декларації з прав людини та ст. 14 (1) Міжнародного 
пакту про громадянські та політичні права, незалежне суддівство є відповідальним за належну реалізацію цього права. Пекінськими тезами передбачено основні принципи щодо обрання суддів на засадах компетентності, неупередженості та незалежності, гарантованого строку перебування на посаді, звільнення, належних умов роботи суддів, забезпечення їх необхідними ресурсами, вирішення адміністративних питань та відносин з виконавчою владою, яка, своєю чергою, може вплинути на суддів через умови оплати праці чи матеріальне забезпечення суддів. Проте виконавча влада не має використовуватися як тиск на суддю чи суддів. Згідно з Пекінськими тезами обмеження незалежності суддів допустимі під час надзвичайних ситуацій, тільки тимчасово та на умовах, передбачених законом. Разом із тим право апеляції має існувати незалежно від надзвичайного стану до юридично кваліфікованого апеляційного суду [11].

Стандарти етичної поведінки суддів встановлені у Бангалорських принципах поведінки суддів. Вони були схвалені Резолюцією Економічної та Соціальної Ради ООН 27 липня 2006 р. Бангалорські принципи адресовані суддям для використання як інструкції та судовим органам для використання як базових принципів регламентації поведінки суддів. Окрім цього, вони покликані сприяти кращому розумінню та підтримці здійснення правосуддя з боку представників виконавчої та законодавчої влади, адвокатів та суспільства в цілому. Бангалорські принципи містять шість показників (принципів): незалежність, об'єктивність, чесність та непідкупність, дотримання етичних норм, рівність, а також компетентність та старанність. Дотримання вищевказаних принципів дасть змогу підтримувати, а для деяких країн, у тому числі і України, - відновити довіру суспільства до судової влади [12].

Одним із найбільш фундаментальних міжнародних актів у сфері судочинства є Рекомендація CM/Rec (2010) 12 Комітету Міністрів Ради Європи державам-членам щодо суддів: незалежність, ефективність та обов'язки, яка ухвалена Комітетом Міністрів Ради Свропи 17 листопада 2010 р. на 1098 засіданні заступників міністрів. Вона містить основні принципи незалежності функціонування судової системи і спрямована на встановлення і зміцнення незалежності суддів як носіїв судової влади.

Вищевказана Рекомендація застосовується щодо кожної особи, яка здійснює судочинство, зокрема й осіб, на яких покладено вирішення конституційних питань, а також щодо непрофесійних суддів. Так, Рекомендація містить положення щодо зовнішньої і внутрішньої незалежності суддів, яка надається їм в інтересах верховенства права і осіб, які домагаються і очікують справедливого правосуддя. Ради суддів, своєю чергою, як незалежні ор- гани мають зберегти незалежність суддів та судової влади загалом і таким чином сприяти ефективному функціонуванню судової системи. А для підвищення якості правосуддя і з метою сприяння його ефективному здійсненню держави мають запровадити системи оцінювання суддів органами судової влади, належними ресурсами для ефективної роботи та відповідними засобами для підтримання міжнародного співробітництва між суддями. Також Рекомендація акцентує, що «основні норми системи оплати праці професійних суддів мають бути визначені законом» і «відповідати їхній професії та виконуваним обов'язкам, а також бути достатніми, щоб захистити їх від дії стимулів, через які можна впливати на їхні рішення» [13].

Свій внесок у розвиток міжнародно-правових стандартів у сфері незалежності судочинства зробила і Україна. Підтримуючи зусилля країн Східної Європи, Південного Кавказу та Центральної Азії у зміцненні незалежності судочинства, Бюро демократичних інститутів та прав людини спільно з Інститутом порівняльного публічного права та міжнародного права імені Макса Планка організували регіональну експертну зустріч з незалежності судочинства у Києві 23-25 червня 2010 року. Близько 40 незалежних експертів узяли участь у цій зустрічі, серед яких - відомі науковці та досвідчені практики з 19 країн-членів ОБСЄ, а також Ради Свропи та, зокрема, Венеційської комісії.

У результаті такої зустрічі було прийнято Київські Рекомендації щодо незалежності судочинства у Східній Європі, на Південному Кавказі та у Середній Азії. Завданням цих рекомендацій є подальше зміцнення незалежності судочинства у вказаних регіонах у рамках трьох напрямів: 1) адміністрування судівництва із наголосом на радах суддівських, органах суддівського самоврядування та ролі голів судів; 2) добір суддів - критерії та процедури, а також 3) відповідальність суддів і суддівська незалежність у процесі судочинства.

Окрема увага була приділена оцінюванню професійної діяльності суддів. В Україні така процедура була запроваджена Законом України «Про судоустрій і статус суддів» № 1402-VIII від 2 червня 2016 року і є зовсім новою. Згідно з Київськими Рекомендаціями статистика щодо ефективності діяльності судів має використовуватися переважно для адміністративних цілей та служити лише одним із факторів для оцінювання суддів. Також оцінювання суддів може бути використане для того, щоб допомогти суддям визначити ті аспекти їхньої діяльності, щодо яких вони можуть висловити бажання вдосконалюватися, а також з метою можливого кар'єрного зростання. Натомість звільнення суддів або інші санкції, які можуть бути застосовані у зв'язку з проведенням періодичних атестацій для суддів, призначених безстроково, є неприпустимими [14]. 


\section{Jimepamypa}

1. Лапкін А.В. Правові основи прокурорської діяльності : науково-практичний посібник. Харків, 2013. 320 c.

2. Баймуратов В.М. Европейские стандарты локальной демократии и местное самоуправление в Украине. Харьков : Одиссей, 2000.80 с.

3. Луць Л.А. Європейські міждержавні правові системи: загальнотеоретична характеристика : дис. ... докт. юрид. наук : 12.00.01. Львівський нац. ун-т ім. І. Франка. Львів, 2004. 447 с.

4. Бринцев В.Д. Стандарти правової держави: втілення у національну модель організаційного забезпечення судової влади : монографія. Харків : «Право», 2010. 464 c.

5. Конституція України : Закон від 28.06.1996 № 254к/96-ВР. База даних «Законодавство України». / ВР України. URL: http://zakon3.rada.gov.ua/ laws/show/254к/96-вр (дата звернення: 22.06.2019).

6. Саленко O.В. Міжнародні стандарти у сфері судоустрою та статусу суддів, їх зміст і класифікація. Jurnalul juridic national: teorie şi practică (Националь ный юридический журнал: теория и практика). 2014. № 3 (7). С. 263-269.

7. Статут Ради Європи: Статут від 05.05.1949. База даних «Законодавство України». / ВР України. URL: http://zakon0.rada.gov.ua/laws/show/994_001 (дата звернення: 22.06.2019).

8. Свропейські та міжнародні стандарти у сфері судочинства / За ред. Д. Вон, I. Зарецька, С. Сученко, В. Валанчюс та ін. Київ. 2015. 708 с.

9. Основніпринципинезалежностісудовихорганів:Резолюція ООН від 13.12.1985. База даних «Законодавство України»./ ВР України. URL: http://zakon4.rada.gov.ua/ laws/show/995_201 (дата звернення: 22.06.2019).

10. Загальна (Універсальна) хартія судді: Хартія Центральної Ради Міжнародної Асоціації Суддів від 17.11.1999. База даних «Законодавство України». BP України. URL: http://zakon2.rada.gov.ua/laws/ show/995_j63 (дата звернення: 22.06.2019).

11. Пекінські тези щодо принципів незалежності суддів юридичної асоціації країн азійського та тихоокеанського регіону (LAWASIA): Міжнародний документ від 01.01.1995. База даних «Законодавство України». / BP України. URL: http://zakon3.rada.gov.ua/ laws/show/995_j78 (дата звернення: 22.06.2019).

12. Бангалорськіпринципи поведінки суддів:Принципи ООН від 19.05.2006. База даних «Законодавство України»./ВРУкраїни. URL: http://zakon2.rada.gov.ua/ laws/show/995_j67 (дата звернення: 22.06.2019).

13. Рекомендація CM/Rec (2010) 12 Комітету Miністрів Ради Європи державам-членам щодо суддів: незалежність, ефективність та обов'язки: Рекомендація Комітету Міністрів Ради Європи від 17.11.2010 № (2010)12 База даних «Законодавство Украйни». / BP України. URL: http://zakon3.rada.gov.ua/laws/ show/994_a38 (дата звернення: 22.06.2019).

14. Київські Рекомендації щодо незалежності судочинства у Східній Європі, на Південному Кавказі та у Середній Азiї. URL: http://www.osce.org/ uk/odihr/86319?download=true (дата звернення: 22.06.2019).

\section{Анотація}

Лісна I. С., Михайлів Т. С. Використання зарубіжного досвіду функціонування судових систем під час проведення судової реформи в Україні. - Стаття.

Термін «міжнародно-правові стандарти» для національного законодавства України вважається найбільш прийнятним позначенням закріплених у різноманітних міжнародних документах норм, стандартизованими правилами поведінки суб'єктів у тих чи інших сферах міждержавного співробітництва. Їх значення для національного законодавства України полягає в тому, що вони є своєрідним орієнтиром. Але такі норми потребують конкретизації і доповнення з боку норм внутрішньодержавного права.

За роки незалежності судова система України піддавалася реформуванню неодноразово. Однак поставлені перед нею цілі до кінця так і не були реалізовані. Для успішного проведення судової реформи простежується одна закономірність - реформування судової системи має відбуватися комплексно, а саме реформування самої судової системи, судоустрою та інших пов'язаних правових інститутів.

Проблема реформування судової влади в Україні натепер виявляє свою актуальність як ніколи, оскільки найважливішими передумовами розвитку громадянського суспільства мають стати якісне, стабільне законодавство та ефективне правосуддя, які здатні реально забезпечувати надійний захист прав і свобод людини, інтересів суспільства і держави, щоб викорінити свавілля і беззаконня. Задля забезпечення ефективного функціонування та подальшого розвитку судової системи необхідне теоретичне осмислення питань реалізації судово-правової реформи. Такі дослідження $\epsilon$ необхідними для вивчення і подальшого врахування проблем, які виникають у процесі здійснення реформи.

Ключові слова: міжнародні стандарти, судочинство, право, Європейський Союз, Організація Об’єднаних Націй.

\section{Summary}

Lisna I. S., Mykhailiv T. Ye. Application of experience of foreign judiciary systems during judiciary reform in Ukraine. - Article.

The term «international legal standards» is considered to be the most acceptable designation of the rules for the national legislation of Ukraine. Such rules are included in various international documents and in standardized rules of conduct of subjects in certain areas of intergovernmental cooperation. Their significance for the national legislation of Ukraine lies in the fact that they perform the function of a guideline. But such rules require adaption to the norms of domestic law.

During the years of independence, the judicial system of Ukraine has been reformed repeatedly. However, the objectives set before it have never been implemented. For a successful judicial reform, one pattern can be traced: reform of the judicial system should take place in a comprehensive manner: reforming the judicial system itself and other related legal institutions.

Therefore, the problem of reforming the judiciary in Ukraine has never been so relevant as nowadays. The most important preconditions for the development of civil society should be quality, stable legislation and effective justice. These can really provide a reliable protection of human rights and freedoms, the interests of society and of the state in order to eradicate tyranny and iniquity. A theoretical understanding of the issues of the implementation of judicial and legal reform is necessary in order to ensure the effective functioning and further development of the judicial system. Such research is necessary for the study and further consideration of problems that arise in the process of reform.

Key words: international standards, judiciary, law, European Union, United Nations. 